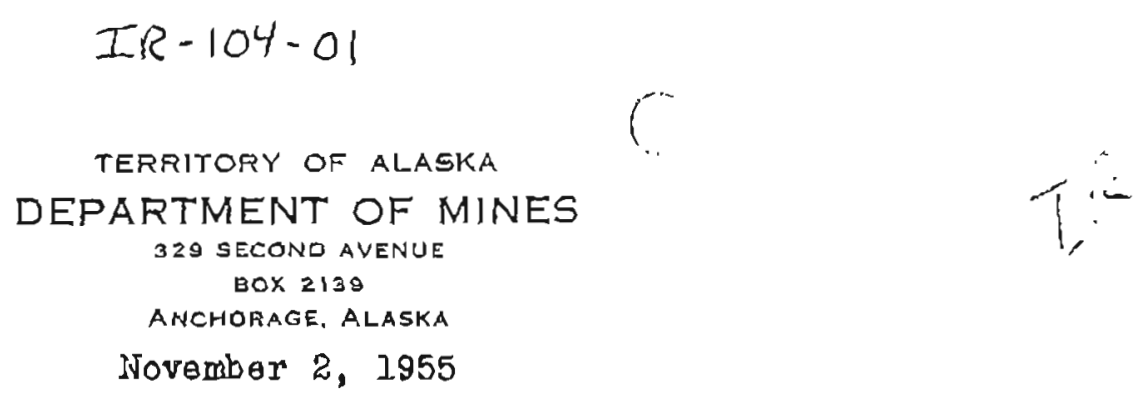

\title{
ITINERARY FEFORI
}

TO: Phil R. Holdeworth, Commissioner of bines

FRoif: Lartir. Jasper, Tonritorial Bining Ingineor

SUBJECT: Visit to operations of Kenai Chrome Company and Alaska Chrome Company, Rod Mounteln hrea, Selnovia Quedrangle.

Finde in the Red Mountain area it was desirable to visit the propertigs and ingpect work done since last visit in Juiy 1953.

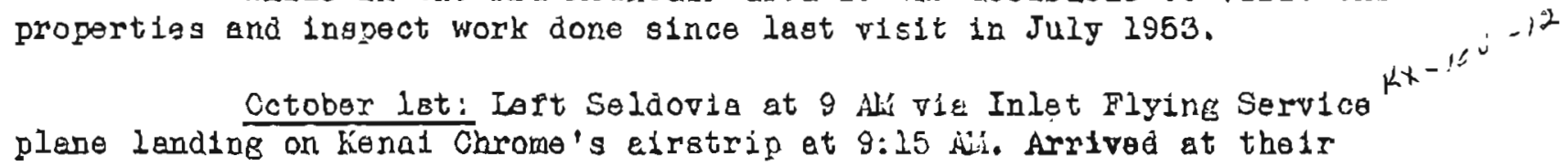
mige comp at 11 ful. Spent 3 hours inspocting tho washing plant and mino worklngs. The mine was found to be iniexcellent condition:"Safety First practices well obgerved. With an early winter season indicated by hoavy snowfall the night before termination of ore haulage to the beach within a fow days was indicated.

Renal Chrome had an averege of 25 men enploged for thelr $4 \frac{1}{2}$ month operating period. Ore deliveries to beach loeding area average 600 tons a weak. Shlpment of 3650 tons was made Sept. 20th, 1955, and the last shipmont of 2500 tong was made for the joar ebout 10 days ago. Mith this last shipment the Government loan will have been peid off in full, and will be the first one ever doing so that bad been procesaed through the Seattle government loan agency.

silake Chrome Compeny: Four men pere working for the conpeny at time of $v i g i t$. An hour was gpent witb them, elving them some lastruction on the teohnique of diemand drilling. A pimited ariliting progrgm was planned to get underway witbin a few dege.

Conglderable rehabliltetion work had been oompleted auring the pest summer and a new adt had been started bolow tbo old vorkings, located at foot of mounteln slope, just above level of the velley floor. The adit had bsen adrenced 75 feet turough the talus end 1 ts face was thought to have reached bedrock just above the floor.

f. maximum of 19 men had been employed for eeveral months. It has boen reported - but not confirmed by the undersigned - that mages had not been paid them, and that the previous management had flually settled their claims by payment of $\$ 300.00$ to each employee. It has been reported that the Zeppe interests of New York had taken over control of the compeng shortly before my visit.

Returned to Selõovia at 4:45 PR vie Inlet Flying Sorviog. kespectrully gubmitied. 
TERRITORY OF ALASKA

DEPARTMENT OF MINES

329 SECOND AVENUE

$\operatorname{BOX} 2139$

ANChORAGE. Alaska

November 2,2955

\section{ITINERAFY REPORT}

TO: Phil F. Holdsworth, Commissioner of litines

FROM: Martin Ji. Jasper, Territorial lining Ingineer

SUBJECT: Examination of chromite ocourrenoes on property of Saldovie Chrome Company, Ino., and the clalms bold under name of $I$. iil. (B1I1) Lyons, Seldovia, located at headwaters of Figh Creak, Seldorla Guadrangle. Trip was made at reçuest of sir. Lyons.

September 26, 1955: Left inchorage at 9:15 All in personal car and arrived at Bomer 3:50 FM. Trip to Seldovia was made in private plene erriving there at 4:25 $\mathrm{BM}$, remaining there for the night.

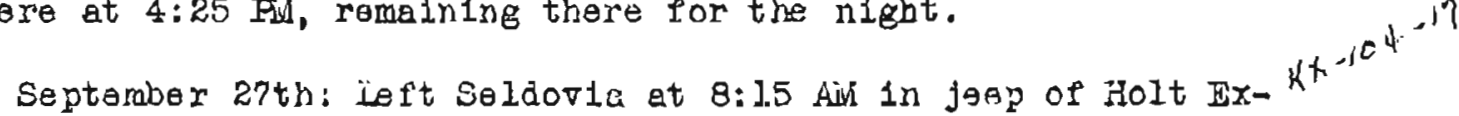
cavating \& Construction Company with Dave Fowler, Robt. Holt, and I. M.

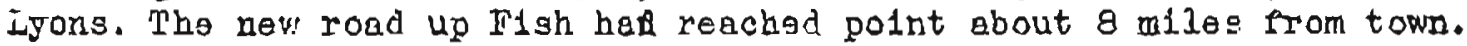
From there the jeop followed tho old treil the last $4 \mathrm{mil}$ los, and reached the Seldovia Chrom Compeny'g "wannigen" near tbolr short alrgtrip about 11 All. Hoavy rains prevalling hed slowed-up road construction and made the last 6 miles tough going by jeep.

The afternoon was spent golng over the several chromite showinge with veasrs iyons, Holt, and Fowler; the latter two had made tantative agreement to do the mining and frelguting of the chroutts ore to seldovir.

September 28th to 30th: That period wes used to run Brunton and chain traverse and mapping of the showings in the area, and the taking of a Ilmited number of samples. A preliminary map on $200^{\prime}$ to $I^{\prime \prime}$ scale wes completed before leaving the camp midafternoon of the 30 th.

Returnod to Selodove for tho nlght about 7 FM on Sept. 30 th.

Cctober 1st: Spent the day at Kenal Chrome Company and ilagke chrome Company properties. Roturned to Seldov1a at 4:45 Pil. Ieft there at 5:20 Ru for Homer. Lalf way across Kachemak Bay ren 1nto zero celling and returned to seldovis for the ulght.

October 2nd: Ieft Seldowie at 7:40 Alik and arrived Homer 8 Alf by privaty plene. Left Homor at $8: 40 \mathrm{AM} \mathrm{by} \mathrm{porsonel} \mathrm{car} \mathrm{and} \mathrm{arrived} \mathrm{at}$ Anchorage at 2:30 Ful.

Respectully submitted,

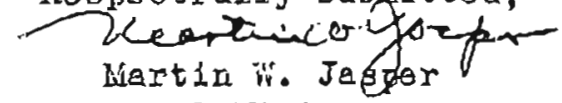

Territoniel :ining Fngineer 